\title{
PHOTOCHEMICAL REDUCTIVE ELIMINATION OF HEXABROMOTELLURATE(IV)
}

\author{
A. VOGLER and A. PAUKNER \\ Universität Regensburg, Institut für Anorganische Chemie, Universitätsstr. 31 , \\ D-8400 Regensburg (F.R.G.)
}

(Received June 30, 1988; in revised form September 2, 1988)

\section{Summary}

In the region between $500 \mathrm{~nm}$ and $300 \mathrm{~nm}$ the electronic spectrum of $\left[\mathrm{TeBr}_{6}\right]^{2-}$ displays absorptions which are assigned to $s \rightarrow p$ transitions. At shorter wavelengths ligand-to-metal charge transfer (LMCT) bands appear. Irradiation of $\left[\mathrm{TeBr}_{6}\right]^{2-}$ in acetonitrile led to a reductive elimination according to the equation $\left[\mathrm{TeBr}_{6}\right]^{2-} \rightarrow\left[\mathrm{TeBr}_{4}\right]^{2-}+\mathrm{Br}_{2}$. Upon LMCT excitation $\left(\lambda_{\text {irr }}=254 \mathrm{~nm}\right)$ the quantum yield was $\Phi=1.3 \times 10^{-2}$ but decreased when the light was absorbed by the longer-wavelength sp bands $(\Phi=0.7 \times$ $10^{-3}$ at $\lambda_{\text {irx }}=436 \mathrm{~nm}$ ).

\section{Introduction}

It has been known for a long time that solutions of compounds containing metal ions with a $\mathrm{s}^{2}$ electron configuration such as Tl(I) [1], $\mathrm{Sn}$ (II) $[1,2-4], \mathrm{Sb}$ (III) $[1,5,6]$ and $\mathrm{Te}$ (IV) are light sensitive (the photolysis of some organotellurium(IV) compounds was investigated but only from the viewpoints of organic photochemistry $[7,8]$ ). In some cases even the stoichiometry of these photoreactions was established. However, mechanistic details were not studied. Quantum yields and their wavelength dependence were not measured. The nature of the reactive excited states is generally unknown. This lack of knowledge is quite surprising in view of potential applications of these photoreactions [2-4]. We are now starting a systematic investigation of the photochemistry of coordination compounds of $\mathrm{s}^{2}$ metals. The present work describes the photoreactivity of $\left[\mathrm{TeBr}_{6}\right]^{2-}$. This complex was chosen for various reasons. The hexahalide complexes of $\mathrm{Te}$ (IV) are well defined not only in the solid state but also in non-aqueous solution. The structures are strictly octahedral and the electronic spectra were studied in absorption [9, 10] and emission [11]. Detailed interpretations of the spectra were reported [9-11]. These results provide a good basis for the investigation of the photochemistry of $\left[\mathrm{TeBr}_{6}\right]^{2-}$. 


\section{Experimental details}

\subsection{Materials}

The compound ( $N$-butyl $\left.{ }_{4}\right)_{2}\left[\mathrm{TeBr}_{6}\right]$ was prepared according to a published procedure [9]. Acetonitrile was Spectrograde and 2-methyltetrahydrofuran was distilled from molecular sieves $(4 \AA)$.

\subsection{Photolyses}

The light source was a Hanovia Xe/Hg $977 \mathrm{~B}-1$ (1 kW) lamp. Irradiations at 254, 270,333, 366 and $436 \mathrm{~nm}$ were achieved with a Schoeffel GM 250-1 monochromator. Solutions of the complexes were photolysed in $1 \mathrm{~cm}$ spectrophotometer cells at room temperature. For quantum yield determinations the complex concentrations were sufficient to achieve essentially complete light absorption (extinction coefficient, about 2 ). The total amount of photolysis was limited to less than $5 \%$ to avoid light absorption by the photoproducts. Absorbed light intensities were determined with a Polytec pyroelectric radiometer that was calibrated and equipped with a RkP-345 detector. Progress of the photolysis was monitored by UV-visible spectral measurements with a Uvikon 810 recording spectrophotometer and a Zeiss PMQ II spectrometer for measurements at selected wavelengths.

\section{Results}

Upon irradiation with light of any wavelength between 254 and $436 \mathrm{~nm}$ the complex anion $\left[\mathrm{TeBr}_{6}\right]^{2-}$ in acetonitrile underwent a photolysis which was accompanied by the spectral changes shown in Fig. 1. The photolysis

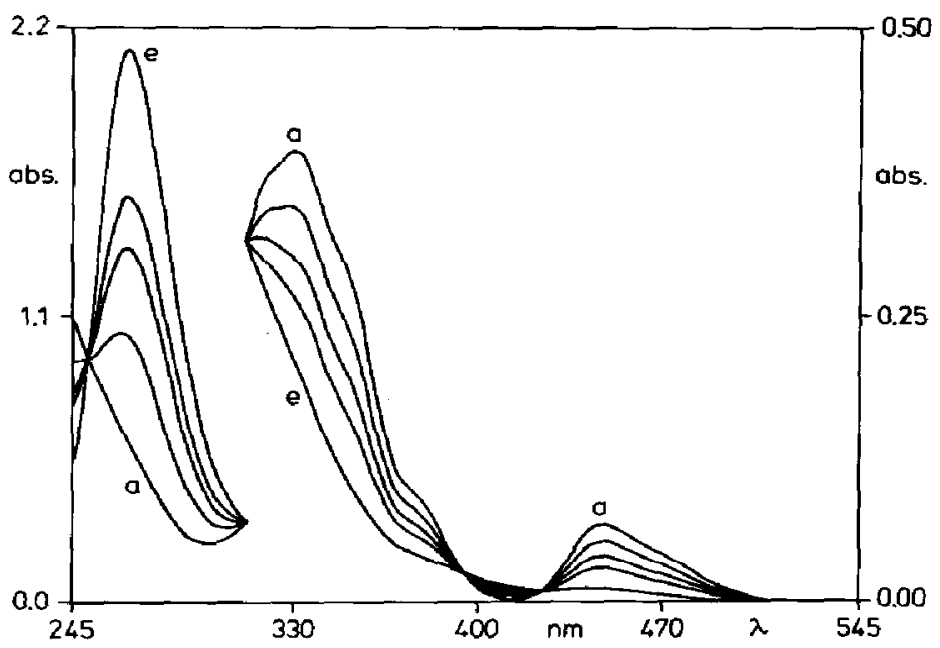

Fig. 1. Spectral changes during the photolysis of $2.15 \times 10^{-5} \mathrm{M}(\mathrm{N} \text {-butyl } 4)_{2}\left[\mathrm{TeBr}_{6}\right]$ in acetonitrile in the presence of $0.05 \mathrm{M}\left(\mathrm{N}\right.$-butyl $\left.\mathrm{l}_{4}\right) \mathrm{Br}$ at (a) $0 \mathrm{~min}$ and (e) $25 \mathrm{~min}$ irradiation time, with $\lambda_{\text {irr }}=332 \mathrm{~nm}$ and a $1 \mathrm{~cm}$ cell. 
could be driven nearly to completion. The new intense absorption maximum at $269 \mathrm{~nm}$ is due to the formation of $\mathrm{Br}_{3}{ }^{-}$which has an extinction coefficient $\epsilon=5.5 \times 10^{4}$ at this wavelength [12]. Bromine which was apparently formed in the photolysis reacted with excess bromide to yield the tribromide anion. (At low concentrations $\left[\mathrm{TeBr}_{6}\right]^{2-}$ is known to dissociate to a small extent [10]. This dissociation and the corresponding spectral deviations were suppressed by the addition of bromide.) The disappearance of [Te$\left.\mathrm{Br}_{6}\right]^{2-}$ was followed by measuring the decrease in extinction at $447 \mathrm{~nm}$ neglecting the residual absorption by the photolysis product. The amount of $\left[\mathrm{TeBr}_{6}\right]^{2-}$ which disappeared on photolysis was equal to the amount of $\mathrm{Br}_{3}{ }^{-}$formed. The quantum yield and its wavelength dependence for the disappearance of $\left[\mathrm{TeBr}_{6}\right]^{2-}$ was determined: $\Phi=1.3 \times 10^{-2}\left(\lambda_{\mathrm{irr}}=254\right.$ $\mathrm{nm}), 4.0 \times 10^{-3}(270 \mathrm{~nm}), 3.0 \times 10^{-3}(333 \mathrm{~nm}), 1.8 \times 10^{-3}(366 \mathrm{~nm})$ and $0.7 \times 10^{-3}(436 \mathrm{~nm})$.

A low temperature photolysis was carried out in order to detect the formation of radicals by electron spin resonance (ESR) spectroscopy. Irradiation $(\lambda>435 \mathrm{~nm})$ of $4.1 \times 10^{-4} \mathrm{M}\left(N \text {-butyl } \mathrm{l}_{4}\right)_{2}\left[\mathrm{TeBr}_{6}\right]$ in a glass $(77 \mathrm{~K})$ of 2-methyltetrahydrofuran which contained $0.05 \mathrm{M}$ ( $N$-butyl -bur $\left._{4}\right) \mathrm{Br}$ did not yield any ESR signal. In particular, no $\mathrm{Br}$ atoms [13] or $\mathrm{Br}_{2}^{-}$radicals [14] were detected. No low temperature irradiation was attempted at wavelengths shorter than $435 \mathrm{~nm}$ since $\mathrm{Br}_{3}^{-}$, which is formed during the photolysis of $\left[\mathrm{TeBr}_{6}\right]^{2-}$, would then absorb light and photolyse to yield bromine atoms. Accordingly, upon higher energy excitation the generation of $\mathrm{Br}$ atoms as primary photoproducts of $\left[\mathrm{TeBr}_{6}\right]^{2-}$ cannot be excluded.

\section{Discussion}

The results support the assumption that $\left[\mathrm{TeBr}_{6}\right]^{2-}$ undergoes photochemical reductive elimination according to the simple stoichiometry

$\left[\mathrm{Te}^{\mathrm{IV}} \mathrm{Br}_{6}\right]^{2-} \longrightarrow\left[\mathrm{Te}^{\mathrm{II}} \mathrm{Br}_{4}\right]^{2-}+\mathrm{Br}_{2}$

Although [ $\left.\mathrm{Te}^{\mathrm{II}} \mathrm{Br}_{4}\right]^{2-}$ has not been described previously, other $\mathrm{Te}$ (II) complexes are known to be stable in non-aqueous solvents [15].

The valence orbitals of tellurium are the $5 \mathrm{~s}$ and $5 \mathrm{p}$ orbitals. For $\mathrm{Te}(\mathrm{IV})$ the $5 \mathrm{~s}$ orbital is filled. It follows that $s \rightarrow p$ and ligand-to-metal charge transfer (LMCT) transitions should occur at relatively low energies. Corresponding absorption bands were clearly identified in the absorption spectrum of $\left[\mathrm{TeBr}_{6}\right]^{2-}[9,10]$ in acetonitrile (Fig. 1). The $s \rightarrow p$ bands $\left(\mathrm{a}_{1 \mathrm{~g}} \sigma^{*} \rightarrow \mathrm{t}_{1 \mathrm{u}} \sigma^{*}\right.$ in $O_{h}$ symmetry) appear at longer wavelengths. The components of the spin-forbidden ${ }^{1} \mathrm{~A}_{1 \mathrm{~g}} \rightarrow{ }^{3} \mathrm{~T}_{1 \mathrm{u}}$ transition show maxima at $\lambda=$ $470 \mathrm{~nm}$ (shoulder, $\epsilon=2135$ ), $447 \mathrm{~nm}(\epsilon=3200$ ), and $380 \mathrm{~nm}$ (shoulder, $\epsilon=4000)$. The spin-allowed $s \rightarrow p$ band $\left({ }^{1} A_{1 g} \rightarrow{ }^{1} T_{1 u}\right)$ appears at $\lambda_{\max }=$ $332 \mathrm{~nm}(\epsilon=17612)$. LMCT transitions which terminate in the $\mathrm{p}$ orbitals $\left(t_{1 u} \sigma^{*}\right)$ occur at higher energies at $\lambda_{\max }=270 \mathrm{~nm}$ (shoulder, $\epsilon=23365$ ). 
Low temperature emission was observed, which originates from the ${ }^{3} \mathrm{~T}_{1 \mathrm{u}}$ sp-excited state which undergoes a tetragonal Jahn-Teller distortion [11].

Shorter-wavelength irradiation at $254 \mathrm{~nm}$ and $270 \mathrm{~nm}$ is associated with LMCT excitation of $\left[\mathrm{Te}^{\mathrm{IV}} \mathrm{Br}_{6}\right]^{2-}$. Since the next lower stable oxidation state is reached by a two-electron reduction, it is not surprising that LMCT excitation leads to a reductive elimination in analogy to other main group metal complexes with a $\mathrm{s}^{\mathrm{o}}$ electron configuration at the metal [16] and to some coordination compounds of certain transition metals such as $\operatorname{Pt(IV)~[17].~Upon~lower~energy~irradiation~into~the~sp~bands~at~} \lambda_{\text {irr }}>\mathbf{3 0 0}$ $\mathrm{nm}$ the reductive elimination still takes place, although the quantum yields decrease. The occurrence of a photoredox process on irradiation of $\mathrm{sp}$ bands is certainly less obvious but has some precedence in the photochemistry of Co(III) ammine complexes [18, 19]. In these cases higher energy LMCT excitation leads to efficient redox photolysis. This reaction also takes place upon longer-wavelength irradiation into dd bands but leads to much smaller quantum yields. It has been suggested that along the reaction coordinate the potential surface of the LMCT state extends to energies below those of the dd states. To a certain extent dd states may then cross over to reactive LMCT states. The same mechanism may explain the residual redox reactivity upon $\mathrm{sp}$ excitation of $\left[\mathrm{TeBr}_{6}\right]^{2-}$. The reactive LMCT state of $\left[\mathrm{TeBr}_{6}\right]^{2-}$ which terminates in the reductive elimination certainly undergoes a large distortion and may thus be populated from sp excited states.

\section{Acknowledgment}

Financial support from the Deutsche Forschungsgemeinschaft and the Fonds der Chemischen Industrie is gratefully acknowledged. We thank Dr. H.-D. Aberle for ESR measurements.

\section{References}

1 G. F. Kirkbright, P. J. Mayne and T. S. West, J. Chem. Soc., Dalton Trans., (1972) 1918 , and references cited therein.

2 M. Paunovic, J. Electrochem. Soc., 127 (1980) $441 \mathrm{C}$.

3 J. F. D'Amico, F. A. Litt and M. A. DeAngelo, J. Electrochem. Soc., 119 (1972) 956.

4 J. F. D'Amico, M. A. DeAngelo, J. F. Henrickson, J. T. Kenney and D. J. Sharp, J. Electrochem. Soc., 118 (1971) 1695.

5 W. Brüll and H. Schlägel, $Z$. A norg. Allg. Chem., 217 (1934) 401.

6 M. U. Belyi and B. A. Okhrimenko, Opt. Spectrosc., 25 (1968) 139, and references cited therein.

7 D. G. Marsh, J. Y. C. Chu, J. W. Lewicki and J. L. Weaver, J. Am. Chem. Soc., 98 (1976) 8432.

8 S. Uemura and S. Fukuzawa, Chem. Lett., (1980) 943.

9 D. A. Couch, C. J. Wilkins, G. R. Rossman and H. B. Gray, J. Am. Chem. Soc., 92 (1970) 307 . 
10 D. J. Stufkens, Rec. Trav. Chim., 89 (1970) 1185.

11 R. Wernicke, H. Kupka, W. Ensslin and H.-H. Schmidtke, Chem. Phys., 47 (1980) 235.

12 A. I. Popov and R. F. Swensen, J. Am. Chem. Soc., 77 (1955) 3724.

13 D. L. Griscom, Solid State Commun., 11 (1972) 899.

14 I. Marov and M. C. R. Symons, J. Chem. Soc. A, (1971) 201.

I. S. Ginns and M. C. R. Symons, J. Chem. Soc., Dalton Trans., (1972) 143.

15 O. Foss, Pure Appl. Chem., 24 (1970) 31.

16 A. Vogler, C. Quett, A. Paukner and H. Kunkely, J. Am. Chem. Soc., 108 (1986) 8263.

17 A. Vogler A. Kern and J. Huittermann, Angew. Chem. Int. Ed. Engl., 17 (1978) 524.

A. Vogler, A. Kern, B. Fusseder and J. Huittermann, Z. Naturforsch. Teil B, 33 (1978) 1352 .

18 F. Scandola, S. Bartocci and M. A. Scandola, J. Phys. Chem., 78 (1974) 572.

19 M. Orhanovic and N. Sutin, Inorg. Chem., 16 (1977) 550. 